RAFA

\title{
The impact of the level of market competition intensity on enterprises activities in area of intellectual capital
}

Prof. Eng. Rafał Prusak Czestochowa University of Technology Faculty of Production Engineering and Materials Technology Department of Production Management and Logistic

\section{Introduction}

Today's market places tough and demanding requirements on companies. These result, on the one hand, from the changes in preferences and the level of customer awareness resulting from such elements as, for example: development of information technology, dissemination of social media, free exchange of ideas, penetration of cultural zones, change of wealth of society, media development. On the other hand, companies themselves, by building market advantage and seeking to increase their own market shares, take actions that often result in shortening the life cycle of products and technology, penetrating the sectors as a result of expanding products with new elements and functionality, or developing consumer awareness of the need for new things. Functioning in such conditions requires that the company possesses not only the relevant resources, knowledge or competencies but also ability to effectively allocate and synergize them to create unique and difficult to copy assets (technology, products, forms of promotion, etc.). An important problem in this context is the development of appropriate methods and techniques for managing the 
resources associated with the fullest possible understanding of the relationship between these methods and the strategic variables, i.e. the specificity of the activity, the age of the sector, market share and intensity of competition. This approach allows for the most effective solutions from the point of view of the current potential and position of the company.

The primary objective of this paper is to try to characterize selected dependencies between the nature of the actions undertaken by enterprises in relation to intellectual capital in the context of the strength of the level of competition in the market. The study was conducted using a questionnaire survey consisted of 23 questions. The questions concerned, among others, issues such as the reasons for taking action in the area of intellectual capital management, the key success factors for the implemented solutions, the effects of implementing these solutions, the basic problems, the approach to the problem and the involvement of the crew.

The research group comprised 70 companies and its structure was as follows:

- due to the size (20 small, 30 medium and 20 large enterprises),

- due to the type of activity (37 manufacturing companies, 33 service companies),

- due to the period of operation (36 new or developing enterprises, 34 mature).

In each individual enterprises questionnaire was filled by a representative of the top management of the company.

\section{The importance of intangible assets and intellectual capital for modern enterprises}

The ability of a company to compete in the marketplace is conditional upon a number of factors, but it can be aggregated into three categories (Czerniachowicz, Szczepkowska 2009, pp. 33-43): human resources (including their competences, knowledge and experience), material resources (natural and capital) and intangible resources (mainly the knowledge level of its development and efficiency). Proper use of these resources (taking into account relationships between them), based on effective planning (providing the right response to market changes), is fundamental to building and maintaining market advantage. At the same time very important is uniqueness and the ability to give individual products, which differ from competitors' offers, are of great importance. To be successful, businesses must be innovative, efficient and flexible, and have hard-tocopy intellectual property. Increasingly, such factors as knowledge, information, customer confidence, norms and values are more and more important. These elements can generate the greatest added value. 
The importance of intangible resources is primarily due to their specific characteristics, such as (Obłój 2001, p. 222):

- possibility of simultaneous use in many places, processes by different entities,

- long-term accumulation process, the need to build within the organization, difficulty in purchasing and standardization,

- no depreciation process, development in use,

- inseparable relationship with human resources - employees create, adapt, implement and creatively use intangible assets.

- Among the potential benefits of using intangible assets can be indicated, among others. (Szara, Pierścieniak 2007, p. 256):

- creating new products and brands,

- building a positive image and reputation of the company,

- optimizing the use of resources,

- building effective internal and external relations,

- creation of innovations, conducting research and development work.

Building a competitive advantage based on intangible assets and intellectual capital is not an easy task, but its nature - and above all the difficulty of copying - makes such a competitive advantage possible to provide a more stable market position for a longer period of time than material resources. According to neoclassical and endogenous growth theories, the accumulation process depends on the efficiency of converting savings into investments. By analyzing the intellectual capital in this context, it should be stated that this capital creates conditions that facilitate the transformation process, which contributes to the multiplication of other forms of capital.

Intellectual capital is defined in the literature rather broadly, and individual authors often unfold the accents in a different way by placing importance on other elements. According to available theories intellectual capital is:

- the difference between the market value and the book value of the organization, i..the sum of hidden assets not included in the balance sheet of the company (Edvinsson, Malone 2001, p. 39),

- the sum of everything that everyone in the enterprise knows and what determines the competitive advantage (Stewart 1997, p. 9),

- the intellectual property of the company and the complex weave of processes and cultures combined with a network of all kinds of relationships and with human capital (Fitz-Enz 2001, p. 23),

- knowledge, experience, technology, customer relationships, professional skills that give organizations a competitive advantage in the marketplace (Edvinsson 1996, p. 356), 
- assets resulting from intellectual activities, extending from acquiring new knowledge (learning) by inventing to creating valuable relationships with others (Wiig 1997, p. 399),

- invisible resources and processes (creating organizational capital and social capital) and human knowledge (creating human capital) (Bratnicki, Strużyna 2001, p. 72).

As with the very concept of intellectual capital, discrepancies can also be observed in views on its structure:

- Edvinsson distinguishes: human capital, customer capital (relational) and organizational capital (structural) (Edvinsson, Malone 1997), A similar division proposes, inter alia, Bukowitz and Williams (Bukowitz, Williams 2000, p. 223), Brennman and Connell (Brennman i Connell 2000, p. 229), Skuza (Skuza 2003).

- Warschat, Wagner i Hauss identify the intellectual capital of employees (including human capital and organizational capital) and the company's intellectual capital (market capital and innovative capital).

- Lichtarski points to the existence of personal capital (knowledge and skills of people) and impersonal capital (documents resulting from the operation of personal capital) (Lichtarski 2003, p. 128), similar views are presented by Ross (Ross 1997, p. 28).

- Brooking distinguishes: market assets (potential related to intangible market assets), human assets (leadership skills, ability to solve problems, etc.), intellectual property (basic competences, human capital, patents, etc.), infrastructure (assets and technologies that enable the organization to function) (Brooking 1999, p. 16).

Understanding the structure of intellectual capital is important because building the competitive advantage based on it depends on the proper identification and use of the relationships between its components (fig. 1). This task is difficult because the components of intellectual capital are not homogeneous, their structure is complex and there are various kinds of relationships and relationships between the elements. It is necessary not only to explain the phenomena occurring at the general level of intellectual capital (macro scale) but also at lower levels (on a micro scale). Partial elements are involved in the main components of intellectual capital, but relationships beyond the "parent" area can result in the raising value of other areas (such as elements from the human capital area can interact with the elements of structural capital). It should be noted that the relationship between the components of intellectual capital must be considered at all levels of enterprise management: strategic (dependencies resulting from enterprise-wide processes, between different entities and levels 
of organization), tactical (concrete processes within enterprises - technological process) and operational (specific workstations and individual employees).

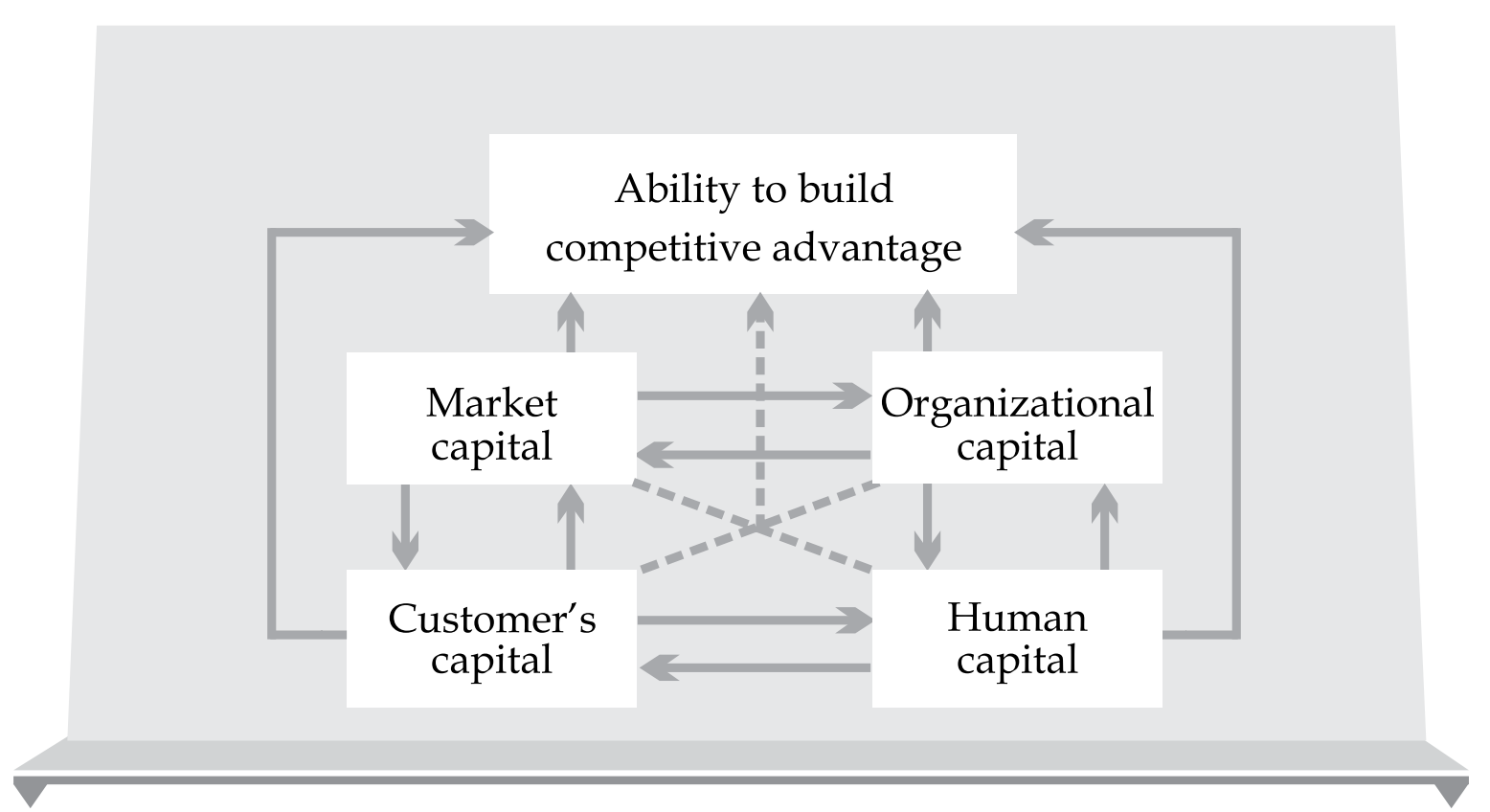

Figure 1. Synergic effect of the elements of intellectual capital

Source: Walczak W. (2010), Zarządzanie wiedzą i kreowanie kapitału intelektualnego w przedsiębiorstwie, „E-mentor", No. 2 (34)

\section{Analysis of results}

This study describes only the selected research items that have been identified. An important area of research was the analysis of the approach of the management staff to intellectual capital depending on the level of competition (table 1). Based on the presented data it can be clearly observed-declared by the managers - growth of the integration of intellectual capital management with the shaping of enterprise strategy. Research has not been subjected to further analysis of this aspect however, it is possible to presume at least some of the factors influencing such results:

- more difficult market reality, resulting from increased competition, forcing enterprises to creative search for new solutions to distinguish their products among other manufacturers' offers, 
- intensive competition may, in certain embodiments, take the form of a price war or technological warfare that significantly lowers the profitability of the business - in this context the efficient use of all the resources of the company, continuous improvement of processes and the emphasis on pro-innovation are of particular importance,

- in sectors where products are of a rather standard character and are less susceptible to differentiation, market success of an enterprise may depend on the skillful design of marketing strategies, building a unique market image, creating lasting relationships with customers, forms of distribution, etc..

Identifying the specific causes of such a result would require further detailed research taking into account the specificity of the functioning of particular companies, the elements characterizing their markets, or evaluating of competitors' strategies.

Table 1. Summary of management responses to intellectual capital

\begin{tabular}{c|c|c|c|c}
\hline Level of intensity of competition & \multicolumn{5}{c}{ Answers } \\
\hline & a & b & c & d \\
\hline low & 14 & 0 & 0 & 0 \\
\hline moderate & 0 & 27 & 6 & 1 \\
\hline high & 0 & 0 & 6 & 16 \\
\hline
\end{tabular}

The answers in the table indicate: a - the problem is not under discussion during strategic analyzes; b - intellectual capital issues are known to management but do not affect strategic decisions; c - intellectual capital management operates only in the context of human resources; $d$-intellectual capital operates in all areas and influences the company's strategic decisions

Source: own study

Only 24 companies have implemented structured actions aimed at actively shaping intellectual capital. Analyzing the data presented in Figure 2 it can be observed that in the group of companies that conduct their business in a highly competitive market each interviewed representatives of executives gave positive answers. It should be mentioned that in most cases, the actions undertaken by companies were not fully systemic, although ex-post analysis demonstrated their apparent development. 


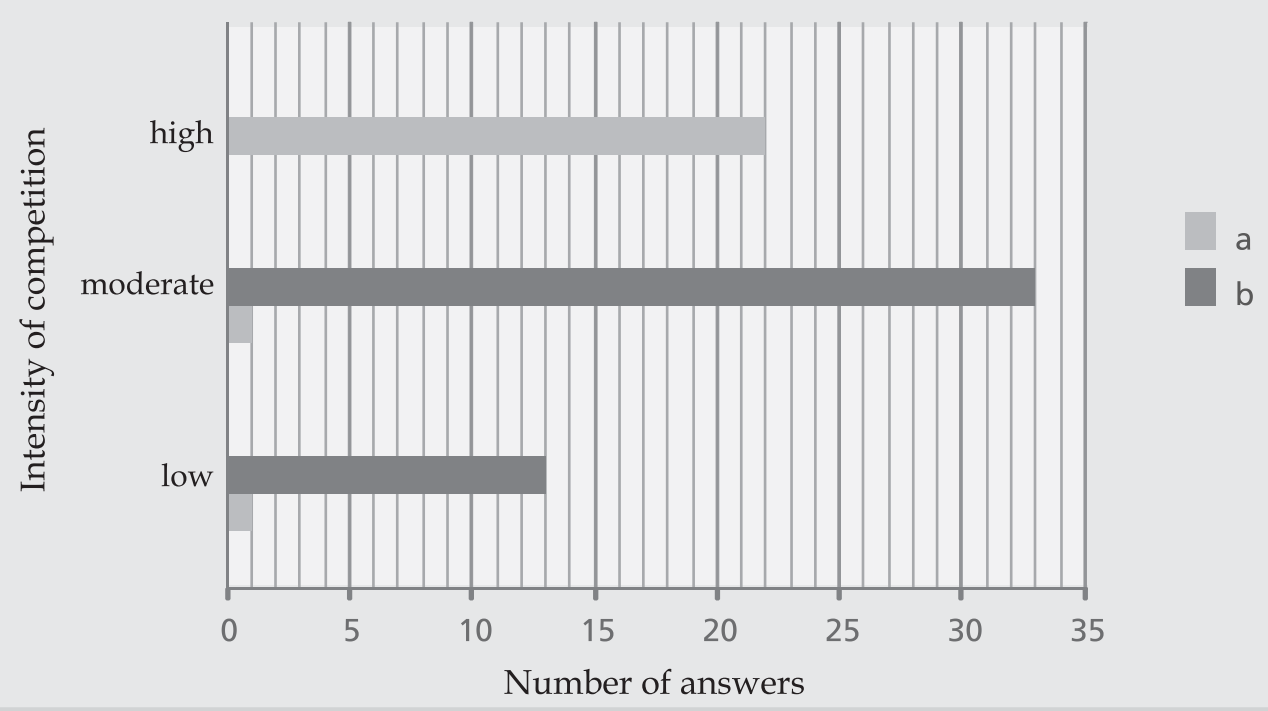

Figure 2. Summary of answers regarding the functioning of intellectual capital management systems in enterprises

The answers in the table indicate: $a$ - yes, $b$ - no.

Source: own study

Table 2 summarizes answers about the causes of interest in the implementation of intellectual capital management elements in enterprise. The most frequently cited response was related to problems in the systematization of knowledge. This has often resulted in lower than expected efficiency of processes, low levels of customer satisfaction, or difficulties in coping with the effects of market events and trends. It also led to the frustration of employees caused by bad organization or irregularities - from the point of view of the specifics of their work positions - in the procedures. Often, the problem reported by the employees was also an insufficient level of freedom that hindered or even prevented them from fulfilling the tasks assigned to them. The second answer with the highest number of indications were the economic effects. Representatives of the executives indicated, among other things:

- improper management of information that results in errors within the organization that prolong the execution of a number of activities,

- lack of mechanisms for effective exchange of experience by employees,

- insufficient recognition of customer needs and preferences, followed by an increased number of complaints or returns, 
- inefficient use of resources, inadequate organization of work, frequent downtimes in machinery and equipment, and employee idleness,

- lack of mechanisms to predict future market trends.

During the study, the group of companies that have not implemented mechanisms of intellectual capital management, was asked about the reasons for such decision. The table in table 3 shows that the main reason was the lack of conviction of executives about the need to manage such resources in the enterprise. This approach was most often justified by the specific nature of the company's activities that did not require such activities. It seems that the reason for such (erroneous) reasoning is primarily the lack of adequate knowledge and experience in managing intangible resources. An important role has also old fashioned management style based on traditional solutions and simple cause - effect relationships. Part of the reason for such attitudes of managers is found in the second most frequently cited answer, namely the lack of appropriate examples and market patterns. Their existence in conjunction with virtually proven effectiveness could change the decision of managers.

Table 2. Summary of responses to the reasons for management interest in intellectual capital management

\begin{tabular}{c|c|c|c|c|c|c}
\hline Level of intensity of competition & \multicolumn{7}{|c}{ Answers } \\
\hline & $\mathrm{a}$ & $\mathrm{b}$ & $\mathrm{c}$ & $\mathrm{d}$ & $\mathrm{e}$ & $\mathrm{f}$ \\
\hline low & 0 & 0 & 0 & 0 & 0 & 1 \\
\hline moderate & 0 & 1 & 0 & 0 & 0 & 0 \\
\hline high & 2 & 8 & 2 & 3 & 7 & 0 \\
\hline
\end{tabular}

The answers in the table indicate: a - positive effects of similar actions in competitors, b - difficulties in systematizing knowledge, resulting in internal and external errors, c - functioning in an industry in which knowledge is the primary factor of competition, $d$ observed deterioration of the market situation of enterprise resulting from the use of obsolete solutions, e - economic premises, $\mathrm{f}$ - others

Source: own study

By analyzing the combination of external factors that influenced the decision to implement the mechanisms for managing intellectual capital (table 4) it can be observed large variation in response. The most frequently mentioned issues 
Table 3. Summary of responses to the reasons for not implementing intellectual capital management mechanisms

\begin{tabular}{c|c|c|c|c|c|c|c|c}
\hline Level of intensity of competition & \multicolumn{9}{c}{ Answers } \\
\hline & $\mathrm{a}$ & $\mathrm{b}$ & $\mathrm{c}$ & $\mathrm{d}$ & $\mathrm{e}$ & $\mathrm{f}$ & $\mathrm{g}$ & $\mathrm{h}$ \\
\hline low & 2 & 11 & 0 & 0 & 0 & 0 & 0 & 0 \\
\hline moderate & 0 & 1 & 6 & 5 & 2 & 6 & 11 & 1 \\
\hline high & 0 & 0 & 0 & 1 & 0 & 0 & 0 & 0 \\
\hline
\end{tabular}

The answers in the table indicate: and - lack of conviction of managers as to the relevance of introducing this solution, b - intellectual capital is not included in the enterprise as an important decision factor, c - business specificity does not require such solutions, $d$ - the problem was considered but was abandoned due to high implementation costs, e - lack of appropriate competence in the organization to manage such a project, $f$ - no specific patterns available that could form the basis of the system, $g$ - lack of market examples of functioning systems, $\mathrm{h}$ - others

Source: own study

Table 4. Answering the question about external factors that influenced the decision to implement the mechanisms for managing intellectual capital

\begin{tabular}{c|c|c|c|c|c|c|c|c|c}
\hline $\begin{array}{c}\text { Level of intensity of } \\
\text { competition }\end{array}$ & \multicolumn{9}{|c}{ Answers } \\
\hline & $\mathrm{a}$ & $\mathrm{b}$ & $\mathrm{c}$ & $\mathrm{d}$ & $\mathrm{e}$ & $\mathrm{f}$ & $\mathrm{g}$ & $\mathrm{h}$ & $\mathrm{i}$ \\
\hline low & 1 & 0 & 0 & 1 & 1 & 0 & 0 & 0 & 0 \\
\hline moderate & 0 & 0 & 1 & 0 & 0 & 1 & 1 & 1 & 2 \\
\hline high & 9 & 12 & 8 & 6 & 10 & 3 & 9 & 6 & 0 \\
\hline
\end{tabular}

The answers in the table indicate (the respondents could choose three options): a - facilitating business contacts and reducing the number of ambiguities and misunderstandings at the negotiating stage, b - increased market prestige reflected in relationships with contractors, c - improvement of the market brand, $d$ - more efficient and faster adaptation to market changes, e - increased levels of customer satisfaction, $f$ - increase the effectiveness of applied marketing solutions, $g$ - increasing the efficiency of acquiring new contractors, $h$ - increase in market share, $\mathrm{i}$ - other 
is related to increasing the prestige on the market resulting from more efficient customer service and increased customer satisfaction. The main premises are therefore the consequence of natural, for modern companies, market orientation. Confirmation of this statement gives the analysis of next indications of the respondents namely facilitating business contacts as a result of better management of knowledge and information and increasing the efficiency of acquiring new customers.

\section{Conlusions}

The efficient use of intangible assets and the management of intellectual capital are becoming important - and in many industries key - aspect of building competitive advantage and shaping market position. Managing these elements is not a simple task. Firstly, because of the nature of this type of resource related, inter alia, to difficulties in their measurement, location or determination of cause - effect relationships in the context of investment. Secondly, the lack of established models, methods, schemes or practices facilitating the development and implementation of appropriate mechanisms in this area. Thirdly, the small versatility of the solutions that make it impossible to simply transfer them between different entities -type of implemented mechanisms depends on the human resources (their knowledge, competence, experience, etc.), industry specificity, market structure, or consumer awareness. Also the level of competition in the sector is important, which in some cases leads to managerial search for new, unused solutions. Properly exploited intellectual capital, in difficult market conditions, can contribute to extending the duration of built market advantages as a result of their more unique and difficult-to-copy nature.

As studies have shown there is a link between the way the approach to the management of intellectual capital and the level of intensity of competition. It has been observed - statistically proven correlation - expressed by the increase declared by the representatives of the executives degree of integration of intellectual capital management with shaping the company's strategy. In addition, it was stated that the most common premises for implementing intellectual capital management mechanisms are: problems with the systematization of knowledge, lower than expected economic effects of business, increase of market prestige, facilitating business contacts and increasing the efficiency of acquiring new clients. On the other hand, the main reasons for not implementing such mechanisms were: lack of confidence of executives about the need to manage 
such resources in the enterprise and lack of appropriate examples and market patterns.

The research allows to analyze only selected issues related to the relationship between competition and the management of intellectual capital in an enterprise. Attempting to describe this issue in detail or modeling cause-andeffect relationships requires detailed research in a larger group of companies.

\section{Summary}

The impact of the level of market competition intensity on enterprises activities in area of intellectual capital

Market activity for today's enterprises means continuing work to better understand the needs of their customers to provide them higher level of satisfaction. Building market advantages using a traditional approach based on material resources becoming less and less likely to increase competitiveness over the long term. The ability to use intangible assets, often more difficult to identify and manage, is becoming a key issue. Proper management of intangible assets can provide the company with unique market advantages that are unique, durable, and difficult to imitate.This study attempts to characterize selected dependencies between the nature of the actions undertaken by enterprises in relation to intellectual capital in the context of the strength of the level of competition in the market.

Keywords: intellectual capital, Level of competition intensity.

\section{Streszczenie}

Analiza wpływu poziomu natężenia konkurencji rynkowej na działania przedsiębiorst $w \mathbf{w}$ obszarze kapitału intelektualnego Działalność rynkowa dla współczesnych przedsiębiorstw oznacza ciągłe podejmowanie działań zmierzających do pełniejszego zrozumienia potrzeb klientów, tak aby w efekcie zapewnić mu wyższy poziom satysfakcji. Budowanie przewag rynkowych z wykorzystaniem tradycyjnego podejścia opartego na zasobach materialnych daje coraz mniejsze szanse na długotrwałe podniesienie własnej konkurencyjności. Kluczowym zagadnieniem staje się więc umiejętność efektywnego wykorzystania zasobów niematerialnych, często trudniejszych 
w identyfikacji i zarządzaniu. Właściwe zarządzanie nimi może bowiem zapewnić przedsiębiorstwu stworzenie uniktowych przewag rynkowych, charakteryzująych się unikatowością, trwałością oraz trudnością $\mathrm{w}$ naśladownictwie. $\mathrm{W}$ niniejszym opracowaniu podjęto próbe scharakteryzowania wybranych zależności pomiędzy charakterem działań podejmowanych przez przedsiębiorstwa w odniesieniu do kapitału intelektualnego a siłą poziomem natężenia konkurencji na rynku.

\section{Slowa \\ kluczowe: kapitat intelektualny, natężenie konkurencji.}

JEL

Classification: D83, J24, O15, O34

\section{References}

1. Bratnicki M., Strużyna J. (2001), Przedsiębiorczość i kapitał intelektualny, Akademia Ekonomiczna, Katowice 2001.

2. Brennman N., Connell B. (2000), Intellectual Capital. Current Issues and Policy of Implications, Journal of Intellectual Capital, No. 3.

3. Brooking A. (1999), Corporate Memory: Strategies for Knowledge Memory, International Thomson Business Press, London.

4. Bukowitz W.R., WIlliams R.L. (2000), The Knowledge Management Fieldbook, Financial Time, Prentice Hall, London.

5. Czerniachowicz B., Szczepkowska M. (2009), Pojęcie $i$ rodzaje konkurencyjności przedsiębiorstw [in:] Białsiewicz M. (ed.), Uwarunkowania i sposoby wzrostu konkurencyjności przedsiębiorstw, Economicus, Szczecin.

6. Edvinsson L. (1996), Developing a Model for Managing Intellectual Capital at Skandia, European Management Journal Vol. I4, No. 4.

7. Edvinsson L., Malone M. (1997), Intellectual Capital, Harper Collins Publishers, New York.

8. Edvinsson L., Malone M. S. (2001), Kapitat intelektualny, PWN, Warszawa.

9. Fitz-Enz J. (2001), Rentowność inwestycji w kapitat ludzki, Oficyna Ekonomiczna, Kraków.

10. Głuszek E. (2004), Zarządzanie zasobami niematerialnymi przedsiębiorstwa, Wydawnictwo Akademii Ekonomicznej im. Oskara Langego we Wrocławiu, Wrocław.

11. Lichtarski J. (2003), Podstawy nauki o przedsiębiorstwie, Wydawnictwo Akademii Ekonomicznej im. Oskara Langego we Wrocławiu, Wrocław.

12. Obłój K. (2001), Strategia organizacji, PWE, Warszawa. 
13. Ross J. (1997), Intellectual Capital. Navigating in the New Business Landscape, MacMillan Business, London.

14. Skuza B. (2003), Zarządzanie kapitałem intelektualnym na przykładzie grupy Skania, [in:] B. Wawrzyniak (ed.), Zarzadzanie wiedza w przedsiębiorstwie, Wydawnictwo Wyższej Szkoły Przedsiębiorczości i Zarządzania im. L. Koźmińskiego, Warszawa.

15. Stewart T. (1997), Intellectual Capital, The New Wealth of Organizations, Nicolas Brealey, London.

16. Szara K., Pierścieniak A. (2007), Kapitat intelektualny jako obszar konkurencji przedsiębiorstw (wybrane aspekty teoretyczne), [in:] Woźniak M.G. (ed.), Nierówności społeczne a wzrost gospodarczy. Gospodarka oparta na wiedzy, Uniwersytet Rzeszowski, Rzeszów 2007.

17. Walczak W. (2010), Zarzadzanie wiedza i kreowanie kapitatu intelektualnego w przedsiębiorstwie, "E-mentor”, No. 2 (34).

18. Wiig K.M. (1997), Integrating Intellectual Capital with Knowledge Management, Long Range Planning, Vol. 30 No. 3. 